$1-1-1916$

\title{
White Burley Tobacco : Experiments and Cultural Directions
}

\author{
I. S. Cook \\ C. H. Scherffius
}

Follow this and additional works at: https://researchrepository.wvu.edu/ wv_agricultural_and_forestry_experiment_station_bulletins

\section{Digital Commons Citation}

Cook, I. S. and Scherffius, C. H., "White Burley Tobacco : Experiments and Cultural Directions" (1916). West Virginia Agricultural and Forestry Experiment Station Bulletins. 152.

https://researchrepository.wvu.edu/wv_agricultural_and_forestry_experiment_station_bulletins/152 @ WVU. It has been accepted for inclusion in West Virginia Agricultural and Forestry Experiment Station Bulletins by an authorized administrator of The Research Repository@ WVU. For more information, please contact ian.harmon@mail.wvu.edu. 
West Virginia University Libraries

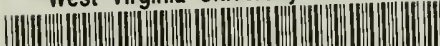

I.n. (n.

308021007621097 



\title{
20yest Yirginia Enminersity Aqricultural Experiment Station
}

\author{
IIORGANTOTN, IT. VA. \\ WHITE BURLEY TOBACCO
}

EXPERIMENTS AND CULTURAL DIRECTIONS

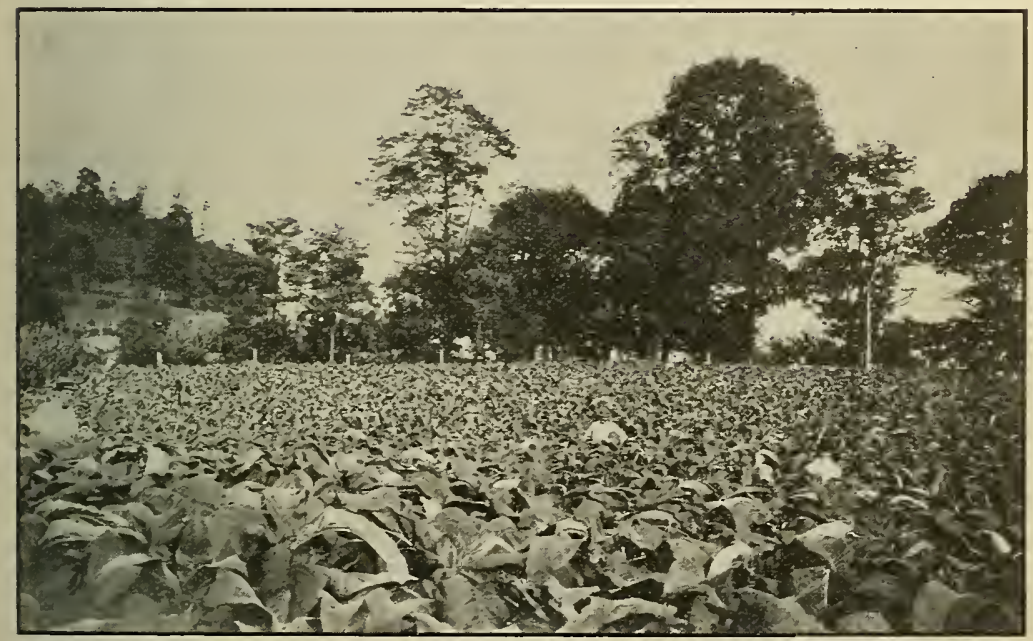

BY

I. S. Cook and C. H. Scherffius

IN CO-OPERATION WITH BUREAU OF PLANT INDUSTRY,

U. S. DEPARTIENT OF AGRICULTURE

The Bulletins and Reports of this Station will be mailed free to any citizen of West Virginia upon written application. Address Director of Agricultural Experiment Station, Morgantown, W. Va. 


\section{THE STATE OF WEST VIRGINIA}

Educational Institutions

\section{THE STATE BOARD OF CONTROL}

JAMES S. LAKIN, President.

Charleston, TV. Va.

A. BLISS McCRUM

Charleston, IV. Va.

J. M. WILLIAMSON

Charleston, W. Va.

The State Board of Control has the direction of the financial and business affairs of the state educational institutions.

\section{THE STATE BOARD OF REGENTS}

M. P. SHAWKEY, President.

Charleston, W. Va.

\section{State Superintendent of Schools}

GEORGE S. LAIDLEY

ARLEN G. SWIGER.

Sistersville, W. Va.

EARL W. OGLEBAY

Wheeling, W. Va.

JOSEPH M. MURPHY

Parkersburg, IV. Va.

The State Board of Regents has charge of all matters of a purely scholastic nature concerning the state educational institutions.

\section{The West Virginia University}

FRANK BUTLER TROTTER, LL.D.

President

\section{AGRICULTURAL EXPERIMENT STATION STAFF}

JOHN LEE COULTER, A.M., PH.D.

BERT H. HITE, M.S.

W. E. RUMSEY, B.S. Agr.

N. J. GIDDINGS, M.S.

HORACE ATWOOD, M.S. Agr

I. S. COOK. Jr., B.S. Agr.

W. H. ALDERMAN, B.S. Agr.

L. M. PEAIRS, M.S.

*O. M. JOHNSON, B.S. Agr.

E. W. SHEETS, M.S. Agr.

FIRMAN E. BEAR, M.Sc.

C. A. LUEDER, D.V.M.

$\dagger$ L. I. KNIGHT, PH.D

A. L. DACY, B.Sc..

FRANK B. KUNST, A.B.

CHARLES E. WEAKLEY, Jr.

J. H. BERGHIUS-KRAK, B.Sc.

J. P. BONARDI, B.Se

ROBERT SALTER, B.S. Agr.

ANTHONY BERG, B.S.

E. C. AUCHTER, B.S. Agr.

L. F. SUTTON, B.S., B.S. Agr

H. L. CRANE, B.S. Agr.

W. B. KEMP, B.S. Agr.

HENRY DORSEY, B.S. Agr.

E. L. ANDREWS, B.S. Agr.

*A. J. DADISMAN, M.S. Agr

J. J. YOKE, B.S. Agr..

*E. A. TUCKWILLER, B.S. Agr.

A. C. RAGSDALE, B.S. Agr..

A. J. SWIFT, B.S. Agr.

*C. H. SCHERFFIUS ....

A. B. BROOKS, B.S. Agr.

C. E. STOCKDALE, B.S. Agr.

Vice-Director and Chemist State Entomologist Plant Pathologist Poultryman Agronomist Horticulturist

Research Entomologist Farm Management Animal Husbandry Soil Investigations Veterinary Science Plant Physiologist Associate Horticulturist Assistant Chemist Assistant Chemist Assistant Chemist Assistant Chemist Assistant Soil Chemist Assistant Plant Pathologist Assistant Horticulturist Assistant Horticulturist Assistant Horticulturist Assistant Agronomist Assistant Agronomist W. J. WHITE. Assistant in Poultry Husbandry Assistant in Animal Husbandry Assistant in Animal Husbaudry Assistant in Animal Husbandry Assistant in Animal Husbandry In Charge of Tobacco Experiments Forester Agricultural Editor

*In co-operation with U. S. Department of Agriculture.

$\rightarrow$ In co-operation with the University of Chicago. 


\title{
White Burley Tobacco
}

\author{
By I. S. COOK and C. H. SCHERFFIUS.
}

In the spring of 1913 an appropriation was made by the Trest Tirginia Legislature to the Experiment Station, for the purpose of conducting experiments with tobacco. Along with this appropriation, the Bureau of Plant Industry of the United States Department of Agriculture furnished additional funds for co-operative tobacco rork and the junior writer of this bulletin was appointed field agent in charge of tobacco inrestigations. This tobacco work was started late in the spring of 1913 and consisted of three fertilizer experiments, located at Nilton, Hurricane and West Hamlin, and a variety test located at Milton. Previous to this time, rery little work had ever been done with tobacco by the IVest Tirginia Experiment Station.

Thile the tobacco-producing area of $T^{T}$ est Virginia is limited, yet the total value of the crop amounts to more than a half-million dollars. The following figures give the amount of tobacco that passed through the Huntington tobacco warehouse for the rearly periods each beginning in July and continuing till July the following year:

\section{Year \\ Production in lbs.}

1912 to 1913

1913 to 1914

1914 to 1915

1915 to 1916
$5,163,676$

$6,023,505$

$4,499,055$

$4,195,690$
Total Value

$\$ 613,862.81$

$712,978.91$

$366,243.11$

$564,982.27$
Ave. Value per cwt.

$\$ 11.88$

11.87

8.10

13.46

'These figures represent the amount of tobacco that was raised in this state and marketed through the Huntington tobacco warehouse. The tobacco growers in counties of Ohio and Kentucky adjoining the Huntington district also market tobacco in Huntington, amounting to about the same number of pounds as that produced in this state, although the value of it is less since the quality is not so good as the tobacco raised in West Virginia. Their average price per hundred pounds is less than that received by West Virginia growers for each year indicated above. 
The type of tobacco grown is the White Burley which is chiefly used in the manufacture of chewing tobacco, although some of the better grades are largely used for pipe and cigarette purposes and to a limited extent for the manufacture of cigars.

\section{SELECTION OF SOIL AND ROTATIONS.}

All tobacco growers prefer a virgin soil, and one on which white oak, walnut, maple, and hickory grow naturally seems to produce tobacco of fine quality. While a virgin soil cannot usually be had, a soil that is fertile, containing an abundance of organic matter, making it loose and mellow, will produce fine tobacco. Good bluegrass sod land produces the best quality of Burley tobacco and a very good yield, but in the tobacco sections of this state very little bluegrass sod land is ever plowed. A clover sod will furnish the next best conditions for a good yield, but the tobacco does not have the quality of that secured from a bluegrass sod. Although a few farmers are rotating their crops and growing clover by liming their land, the majority of farmers have not limed and consequently their meadows are composed almost entirely of timothy and orchard grass. When a tobacco crop follows this kind of sod not nearly such good yields are secured as after clover or some other leguminous crop, although the quality of leaf is better. Therefore, the grower must determine whether he wants a high yield or the best quality of tobacco.

The methods of cropping the land in the tobacco sections of this state are so haphazard that farmers do not know from one year to the next on what fields they are going to grow tobacco. It is more necessary to have a definite and fixed rotation in tobacco growing than in many other kinds of farming. The following rotation may be practiced with good results in the tobacco growing districts:

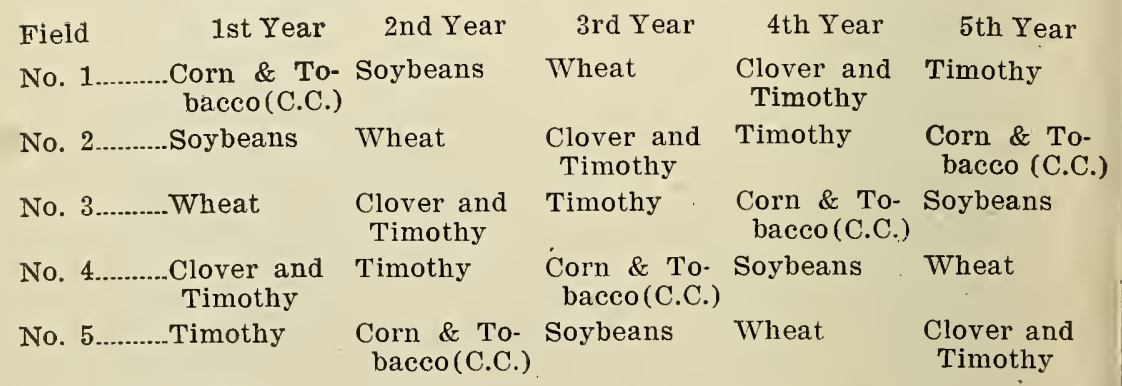

(C. C.)-Cover crop of rye. 
This five-year rotation will require five small areas of ground. The corn and tobacco crops are intended to occupy the same area of land as is occupied by any one of the other crops. Farmers who grow tobacco will also grow corn, and tobacco following corn or corn following tobacco is not a good practice. Since a smaller acreage of tobacco is usually grown than that of hay or wheat it would be a better practice to divide the field for the corn and tobacco crops, devoting onehalf of the area to each crop. The advantages of this rotation over others are several but that of producing the highest quality of tobacco and at the same time keeping up the fertility of the soil by growing a cover crop and two leguminous crops in the rotation is of sufficient importance to recommend such a rotation. By growing soybeans for hay following the corn and tobacco crops there is sufficient time for getting a good growth of rye before turning under to sow soybeans which are usually sown during the latter half of May or first of June.

If not enough land is available for dividing it into five tracts, it will be necessary to practice a three or four year rotation such as the following:

\section{Field}

No. 1

No. 2

No. 3 1st Year

Corn and

Tobacco

Wheat

Clover and

Timothy 2nd Year

Wheat

Clover and Timothy

Corn and

Tobacco 3rd Year

Clover and Timothy

Corn and

Tobacco

Wheat

This rotation may be made into a four-year rotation by not plowing the clover and timothy sod after the first hay crop but leaving it for a timothy crop the second year, then plowing for tobacco and corn, one-half of the field being devoted to corn and the other half to tobacco as in the fiveyear rotation. While this rotation does not provide a green manuring crop nor a second nitrogen-gathering crop as in the first rotation, it is far better than no definite rotation. The fertility of the soil can be maintained or increased by making liberal use of high grade fertilizers and by utilizing all of the farm manure produced on the place.

Tobacco growers must avoid growing corn after tobacco or tobacco after corn as these two cultivated crops are entirely too hard on the land when following each other, and it will be necessary either to leave out one of these from the rotation or to divide the area of the field between them. Many farmers believe that tobacco is harder on land than any other crop, but the bad practice of following no definite rotation has been 
responsible for this idea. Corn or timothy may deplete the soil of its fertility as rapidly as tobacco if no green manuring or leguminous crops are in the rotation in which they are grown. Tobacco, being a crop capable of bringing in large cash returns, so tempts farmers to grow it often on the same land that the fertility question is orerlooked.

The best tobacco soils are the Huntington silt loam, Holston silty clay loam, Holston silt loam, and Tyler silt loam. The Huntington silt loam produces the best-paying crops of tobacco and extends over a larger area than any of the other soil types mentioned. A typical section where this soil occurs is along Beech Fork of the Twelvepole Creek. The Holston silty clay loam lies along the Guyandotte Valley Railroad and is good corn and tobacco soil. While it does not extend over as large an area as the Holston silt loam, the vield and quality of the tobacco grown on it are usually better.

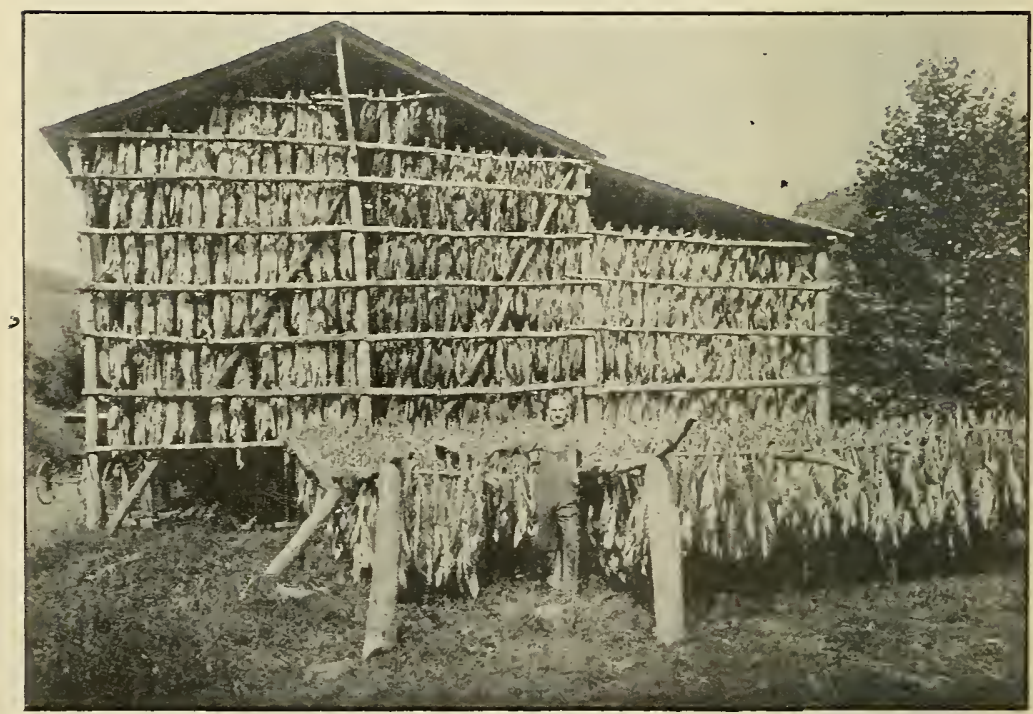

A Type of Tobacco Curing Shed too Commonly Used. 


\section{VARIETIES.}

The variety grown almost exclusively in the tobacco sections is that known as Lockwood's Burley. There is no question but that this variety has given excellent results in the past. Owing perhaps to the lack of attention given to the selection of seed from the better plants, this variety is not giving as high a yield of the best quality of tobacco as it formerly did. In the spring of 1913 a variety test was conducted at Nilton which included eight varieties, seven of which were secured from the Kentucky State Experiment Station and the other being Lockwood's Burley. The plots were 1-30 of an acre in size and Lockwood's Burley was grown on every third plot. The following table gives the results of the test:

\section{Variety}

Hope's Standup Burley

Holley's White Burley

Renaker's Standup Burley

Hisle's White Burley

Station Standup Burley

Lockwood's Burley

Selection of White Twist Bud

Hullett's White Burley.

\section{Lbs. per Plot}

78.5

70.7

77.3

71.5

55.8

46.5

71.0

73.5

Yield per Acre

Lbs.

2355

2121

2319

2145

1674

1395

2130

2205

The seed of these varieties was not sown until April 23, which was very late for growing good plants. This was due to the fact that plans for carrying on the tobacco tests were not completed until quite late in the spring. The plants were transplanted July 5 which was too late to get the tobacco matured properly. The result was that considerable damage was done to the tobacco in the barn by an early freeze in the fall. Two or three of the varieties tested gave promise of proving superior to Lockwood's Burley in quality as well as in yield.

\section{CULTURAL DIRECTIONS.}

There is no definite time for sowing tobacco seed any further than to say that it may be sown either in winter or in spring, and it is undecided which is the better time. In fact. winter sowing will suit one farmer while spring sowing will suit another. One advantage in sowing in the winter is to get the work done before spring is at hand because in spring farmers are usually very busy and are more likely to neglect putting their seed beds in proper condition. In winter the 
ground is wet and more burning is required, so the gain is about equal to the loss. Good plants may be had, though, either from winter or spring sowing, but spring sowing should not be later than the last of March.

The plant bed should be made in some good fertile place having good drainage and being well exposed to the sun. It is best to find some place in the woods where the soil is loose and friable. This soil usually has enough decayed vegetable matter and is also handy to plenty of wood, shrubbery, brush, etc. which may be used for burning.

The main object in burning a tobacco bed is to kill insects, and weed and grass seeds that may be in the soil. A good method is to lay small poles or skids over the area to be burned, at intervals of from three to four feet, and then to pile brush and dry wood on one end of the skids. After setting fire to the brush the burning material is pulled forward a few feet on the skids whenever the soil becomes sufficiently heated and sterilized to a depth of two or three inches. It will be necessary to pile more brush on from time to time in order to get the soil evenly burned. After removing all debris, the soil is thoroughly spaded to a depth of four or five inches. Before seeding, a fertilizer consisting of 5 pounds of dried blood and 2 pounds of acid phosphate for each 100 square feet of bed is to be worked into the soil. The rate of sowing should be a level teaspoonful of seed to 100 square feet of bed. If sown too thick, the plants will be tall and spindling, while if sown too thin they will be too short for setting and getting desirable results. After seeding, the bed should be covered with canvas to protect it from cold winds. The canvas should be allowed to remain till a week or ten days before time for setting. It can then be removed in order that the plants may harden before being taken up for transplanting; otherwise, the hot sun might kill the young tender plants.

\section{PREPARATION OF SOIL.}

The ground intended for tobacco should be plowed in the fall, if there is no danger of washing, especially if it is sod land or land on which weeds have been allowed to grow. If it is newly cleared land or land free from dry vegetation, it may be plowed early in the spring and the results obtained will be satisfactory.

Sufficient time after plowing is needed to get the ground in a fine tilth, so as to give the best possible conditions for starting the plants to growing rapidly. The principal reason why sod land should be plowed in the fall is to give the sod 
time to rot, and also to kill insects that might prove injurious to the young tobacco plants. Early in the spring the land should be pulverized thoroughly by cultivating with a disk harrow and dragging with a peg tocth harrow. Sometimes it is necessary that the ground be re-broken before harrowing and dragging. The next step is laying off the ground. This, however, will be discussed under the subject of transplanting.

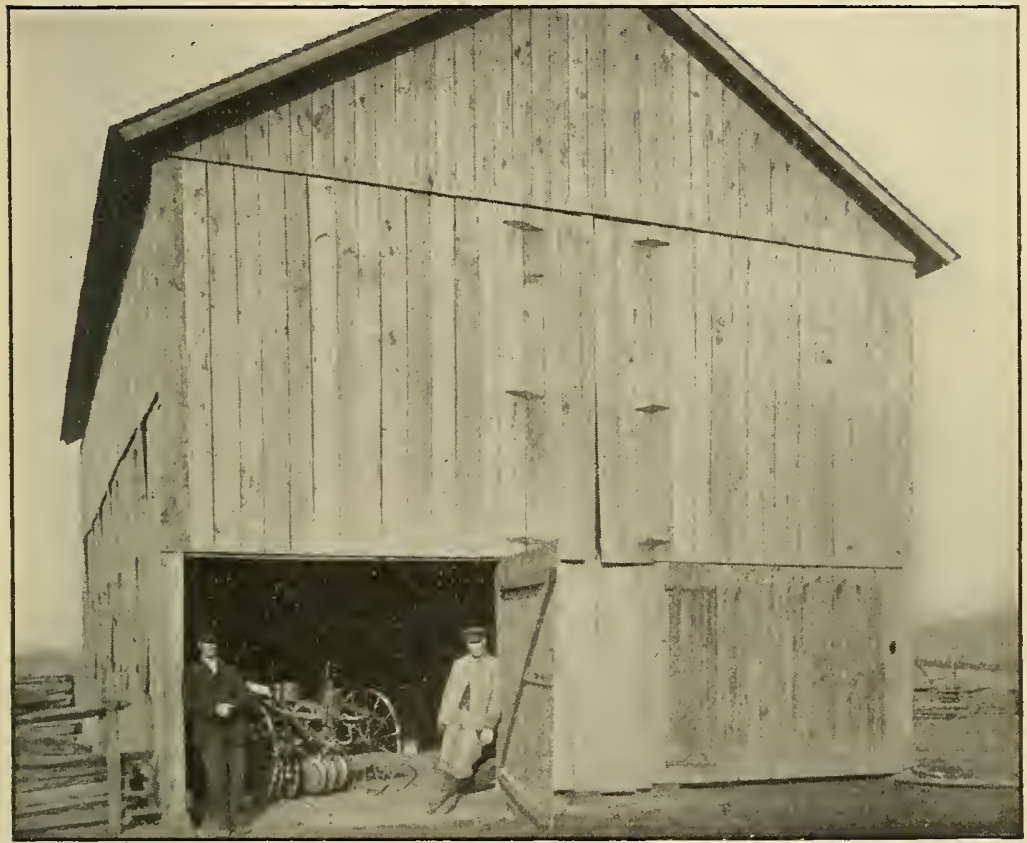

A Good Type of Air Curing Tobacco Barn.

\section{FERTILIZERS.}

The fertilizer requirements of different soils for growing good tobacco vary considerably, due to the way the soil has been handled in previous years. The amount of plant food constituents required for a tobacco crop of 1000 pounds per acre including stalks is as follows:

Nitrogen 46 lbs.

Phosphoric acid Potash 8 " 35 “

These figures show that the tobacco plant uses a relatively small amount of phosphoric acid, yet it has proved profit- 
able to apply a fertilizer relatively high in this plant food constituent. This is due to the fact that phosphorus in West Virginia soils is in combination with elements which form insoluble compounds and unless some available phosphorus is applied the maximum production will not be attained. What has been said in regard to the available supply of phosphorus applies also to potassium. While IVest Virginia soils contain large quantities of potash compounds, crops requiring relatively large amounts of this plant food constituent cannot secure their requirements. This deficiency of available potash is probably due to the lack of decaying vegetable matter and lime in the soil. The system of farming followed in the tobacco districts did not provide for a leguminous or green manuring crop and consequently the soils have been robbed of their nitrogen to such an extent that it will not be profitable to farm them until organic matter and nitrogen are restored.

The fertilizer work that has been carried on for the last three years has not been entirely satisfactory, owing to the fact that it was not possible to lease sufficient land from farmers for a period of years so that a definite rotation could be carried out. Since a different area of land at each place had to be rented every year, all plots were either duplicated or repeated four times at each location in order to make the work as accurate as possible. The following table gives the results of two years' test at Hurricane. No work was done at Hurricane during 1915.

\begin{tabular}{|c|c|c|c|c|}
\hline Fertilizing Materials & $\begin{array}{c}\text { Acid } \\
\text { Phosphate } \\
\text { Per Acre }\end{array}$ & $\begin{array}{l}\text { Nitrate of } \\
\text { Soda } \\
\text { Per Acre }\end{array}$ & $\begin{array}{c}\text { Sulphate of } \\
\text { Potash } \\
\text { Per Acre }\end{array}$ & $\begin{array}{l}\text { Yields in } \\
\text { Lbs. } \\
\text { Per Acre }\end{array}$ \\
\hline No fertilizer & \multirow{4}{*}{200} & \multirow{3}{*}{125} & \multirow{3}{*}{80} & \multirow[b]{2}{*}{967} \\
\hline $\begin{array}{l}\text { Nitrate of Soda, Acid Phos- } \\
\text { and Sulphate of Potash...... }\end{array}$ & & & & \\
\hline $\begin{array}{l}\text { Acid Phosphate and Sulphate } \\
\text { of Potash }\end{array}$ & & & & 897 \\
\hline $\begin{array}{l}\text { Local fertilizer, } .82-8-4,400 \mathrm{lbs} \text {. } \\
\text { per acre }\end{array}$ & & & & 807 \\
\hline Nitrate of Soda.............. & & \multirow[t]{2}{*}{300} & \multirow{3}{*}{300} & 870 \\
\hline Sulphate of Potash... & & & & 800 \\
\hline Acid Phosphate & \multirow[t]{2}{*}{300} & & & 765 \\
\hline $\begin{array}{l}\text { Barnyard manure, } 10 \text { tons } \\
\text { per acre }\end{array}$ & & & & 1045 \\
\hline
\end{tabular}

The soil on which this fertilizer test was conducted is known as the Tyler silt loam which is rather a heavy soil, often greatly in need of drainage. Due to the way in which this soil has been handled in the past, it appears to be greatly 
in need of nitrogen but with the addition of both acid phosphate and sulphate of potash a considerable increase in the yield of tobacco was secured. Manure has given the best results of all fertilizing materials applied. Not many tobacco farmers keep any more livestock on their farms than is necessary to farm their land and furnish milk for the home. The most common fertilizer used is one analyzing one percent ammonia, eight percent phosphoric acid and four percent potash, costing $\$ 25.00$ per ton two years ago. It has given only a slight increase in yield, due perhaps to the low percentage of nitrogen which it carries.

The results of the fertilizer test at Milton are shown in the following table. Ground limestone was applied to onehalf of all the plots at the rate of 2000 pounds per acre.

\begin{tabular}{|c|c|c|c|c|c|}
\hline Fertilizing Materials & $\begin{array}{l}\text { Acid } \\
\text { Phosphate } \\
\text { Per Acre }\end{array}$ & $\begin{array}{l}\text { Nitrate of } \\
\text { Soda } \\
\text { Per Acre }\end{array}$ & $\begin{array}{l}\text { Sulphate of } \\
\text { Potash } \\
\text { Per Acre }\end{array}$ & $\begin{array}{l}\text { Manure } \\
\text { Tons } \\
\text { Per Acre }\end{array}$ & $\begin{array}{l}\text { Yields in } \\
\text { Lbs. } \\
\text { Per Acre }\end{array}$ \\
\hline No fertilizer & & & & & 1287 \\
\hline $\begin{array}{l}\text { Acid Phosphate, Ni- } \\
\text { trate of Soda and } \\
\text { Sulphate of Potash }\end{array}$ & 200 & 100 & 100 & & 1580 \\
\hline $\begin{array}{l}\text { Acid Phosphate, Ni- } \\
\text { trate of Soda and } \\
\text { Sulphate of Potash }\end{array}$ & 260 & 60 & 80 & 8 & 1440 \\
\hline $\begin{array}{l}\text { Acid Phosphate and } \\
\text { Sulphate of Potash }\end{array}$ & 300 & 00 & 100 & & 1370 \\
\hline $\begin{array}{l}\text { Nitrate of Soda and } \\
\text { Sulphate of Potash }\end{array}$ & & 225 & 175 & & 1405 \\
\hline
\end{tabular}

Lime alone did not increase the yield of tobacco but the limed halves of the plots receiving fertilizers produced 126 pounds per acre more than the halves receiving no lime.

In addition to the regular fertilizer work at Milton in 1914 , one acre of land was rented for the purpose of determining the net profit from growing tobacco where a high grade mixed fertilizer was applied at the rate of 700 pounds per acre and the necessary cultivations given to the tobacco. The fertilizing materials applied were 300 pounds of acid phosphate, 200 pounds of nitrate of soda and 200 pounds of sulphate of potash.

Fertilizer tests have been carried on in the Guyandotte Valley in both Cabell and Lincoln counties, on the Holston silty clay loam soil which is recognized by all tobacco growers as being perhaps the best soil type for raising Burley tobacco. 
The first two years' test, indicating the fertilizing materials applied and the results obtained, is shown in the following table:

\begin{tabular}{|c|c|c|c|c|}
\hline Fertilizing Materials & $\begin{array}{l}\text { Acid } \\
\text { Phosphate } \\
\text { Per Acre }\end{array}$ & $\begin{array}{l}\text { Nitrate of } \\
\text { Soda } \\
\text { Per Acre }\end{array}$ & $\begin{array}{l}\text { Sulphate of } \\
\text { Potash } \\
\text { Per Acre }\end{array}$ & $\begin{array}{l}\text { Yields in } \\
\text { Lbs. } \\
\text { Per Acre }\end{array}$ \\
\hline No fertilizer & & & & 1073 \\
\hline $\begin{array}{l}\text { Acid Phosphate, Nitrate of } \\
\text { Soda and Sulphate of Potash } \\
\text { Local fertilizer, } .82-8-4,400 \text { lbs. } \\
\text { per acre }\end{array}$ & 200 & 100 & 100 & $\begin{array}{l}1325 \\
1116\end{array}$ \\
\hline $\begin{array}{l}\text { Acid Phosphate, Nitrate of } \\
\text { Soda and Sulphate of Potash }\end{array}$ & 260 & 60 & 80 & 1265 \\
\hline $\begin{array}{l}\text { Acid Phosphate and Sulphate } \\
\text { of Potash }\end{array}$ & 300 & & 100 & 1250 \\
\hline $\begin{array}{l}\text { Nitrate of Soda and Acid } \\
\text { Phosphate }\end{array}$ & 175 & 225 & & 1290 \\
\hline $\begin{array}{l}\text { Nitrate of Soda and Sulphate } \\
\text { of Potash }\end{array}$ & & 225 & 175 & 1280 \\
\hline $\begin{array}{l}\text { Nitrate of Soda } \\
\text { Acid Phosphate }\end{array}$ & 300 & 300 & & 1260 \\
\hline
\end{tabular}

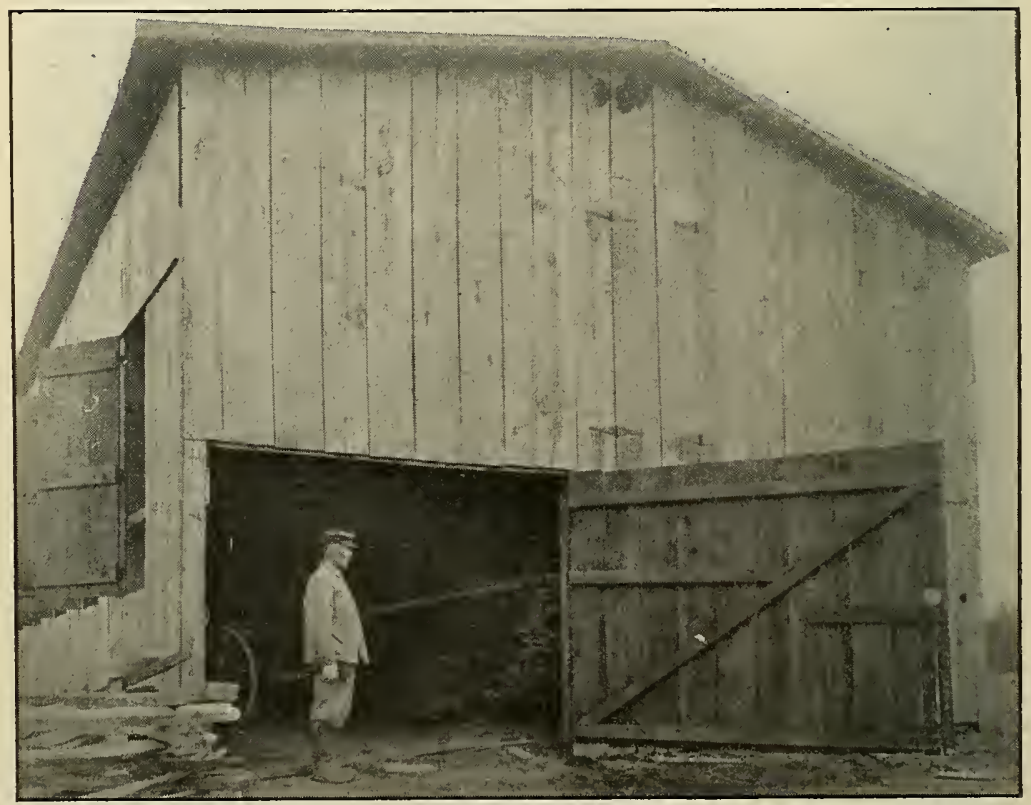

An Inexpensive Curing Barn with Good Ventilation. 
Nitrogen seems to be the controlling element since the yield of tobacco on this type of soil was either high or low, depending upon the amount of nitrogen that was applied. A fertilizer with a relatively high percent of phosphorus, as compared with potassium, will no doubt pay better on this soil than the reverse as indicated by the yield of tobacco, and especially would this conclusion be reached if grain were grown in rotation with tobacco on this soil type.

In 1915 the plan of the tobacco fertilizer test on this soil type was changed and the different fertilizing materials were applied in sufficient amounts so that no one material would be lacking for a maximum yield. All plots were repeated four times with every fifth one a check plot.

\begin{tabular}{|c|c|c|c|c|}
\hline Fertilizing Materials & $\begin{array}{c}\text { Acid } \\
\text { Phosphate } \\
\text { Per Acre }\end{array}$ & $\begin{array}{l}\text { Nitrate of } \\
\text { Soda } \\
\text { Per Acre }\end{array}$ & $\begin{array}{c}\text { Sulphate of } \\
\text { Potash } \\
\text { Per Acre }\end{array}$ & $\begin{array}{l}\text { Yields in } \\
\text { Lbs. } \\
\text { Per Acre }\end{array}$ \\
\hline No fertilizer & & & & 1360 \\
\hline Acid Phosphate & 500 & & & 1410 \\
\hline $\begin{array}{l}\text { Acid Phosphate and Nitrate } \\
\text { of Soda }\end{array}$ & 500 & \multirow[t]{2}{*}{250} & & 1700 \\
\hline $\begin{array}{l}\text { Acid Phosphate and Sulphate } \\
\text { of Potash }\end{array}$ & \multirow[t]{2}{*}{500} & & \multirow[t]{2}{*}{200} & 1475 \\
\hline Acid Phosphate, Nitrate of & & \multirow[b]{2}{*}{250} & & \\
\hline Soda and Sulphate of Potash & 500 & & 200 & 1710 \\
\hline $\begin{array}{l}\text { Acid Phosphate, Dried Blood } \\
\text { and Sulphate of Potash............. }\end{array}$ & 500 & $250 *$ & 200 & 1650 \\
\hline $\begin{array}{l}\text { Acid Phosphate, Nitrate of } \\
\text { Soda, Sulphate of Potash } \\
\text { and Lime }\end{array}$ & \multirow[t]{2}{*}{500} & 250 & 200 & 1700 \\
\hline $\begin{array}{l}\text { Nitrate of Soda and Sulphate } \\
\text { of Potash }\end{array}$ & & 250 & 200 & 1590 \\
\hline
\end{tabular}

*Dried blood.

†Lime, 2000 lbs. per acre.

In 1914 one acre of land was set aside at Milton for the purpose of determining the approximate cost of growing tobacco when a high grade fertilizer was applied at the rate of 700 pounds per acre. Ground limestone was applied at the rate of one ton per acre and a fertilizer mixture of 200 pounds sodium nitrate, 300 pounds acid phosphate and 200 pounds potassium sulphate was used on the acre of land. It would perhaps have been better if tankage or dried blood had been used as the carrier of nitrogen in order to produce a leaf of finer texture. 
Yield of tobacco secured on one acre. Weight after reaching market 1640 pounds

Cash received from Huntington Tobacco Warehouse Co. Cost of growing and marketing tobacco. $\$ 98.65$ 66.40

Net returns for one acre $\$ 32.25$

The following itemized expense account shows the cost of different operations in growing the tobacco:

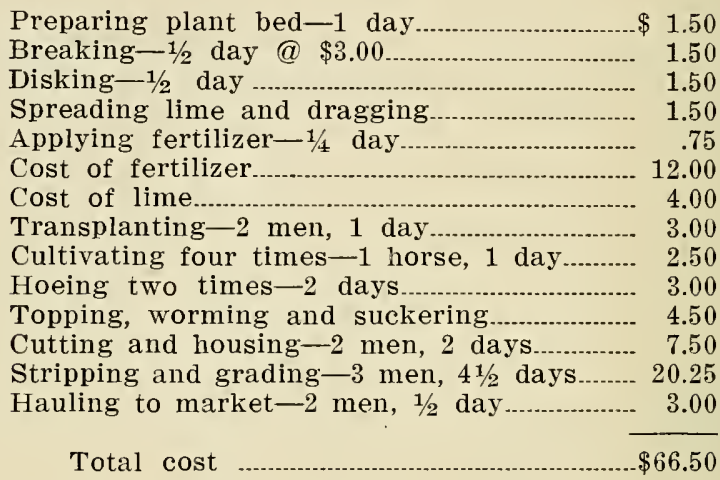

No doubt some of these items cost more than they would cost the average farmer, but the net returns show that where lime and a liberal application of a high grade fertilizer were used a good profit was secured, and the land was kept in a fairly rich condition. In fertilizing Burley tobacco some attention should be given to the carrier of nitrogen. In other states, fertilizer tests show that inorganic carriers of nitrogen produce tobacco having a coarser texture than do organic carriers. So far no coarseness of leaf has been noticed with nitrate of soda on soils of West Virginia, but further tests may give different results. The tobacco on each plot of the 1915 test was valued by a tobacco buyer but very little variation existed between the different plots. The tobacco grown with complete fertilizer with nitrate of soda as the carrier of nitrogen averaged one cent per pound higher than that grown with dried blood as the carrier of nitrogen, due to the fact that there was a larger percent of bright leaf produced on the nitrate of soda plot. 


\section{TRANSPLANTING.}

When the young plants have grown about five inches high, they are ready for transplanting. They should be transplanted in rows about $3 \mathrm{I} / 2$ feet apart, and spaced about 18 inches in the row. These distances, however, are determined largely by the soil on which the tobacco is to be grown. If the soil is very fertile the plants may be set closer, while on a very thin soil, they may be given more room. For fertile soils, close setting tends to produce tobacco with a thin silky leaf which will cure brighter than it would otherwise. In setting small plants, care should be taken not to bruise them or to destroy the plants. In setting, a good method is as follows: mark the rows off first and then drag a chain, roll a wheelbarrow or use some similar device across the rows, making the tracks the distance apart that you wish to have the plants. Then set one row on the checks or crosses and the next between the crosses and so on. This method gives all rows the same number of plants and also gives them an even distribution. It is not a good idea to "guess" at the distances, especially when more than one man is setting the plants, as this is sure to cause irregularity.

In two or three days after the plants have been set, the field should be gone over and any plants that have died may be replaced by fresh ones. This operation should be repeated the following week, since it is essential to have, as nearly as possible, a perfect stand.

\section{CULTIVATION OF PLANTS.}

About the time the plants have started to grow, the field should be given a shallow but thorough cultivation. This operation should be repeated at least once a week until the plants have reached such growth that cultivating will injure them, or until the plants are about ready to be topped. The cultivation of tobacco should always be thorough but shallow. Keep the top of the soil worked into a good loose mulch, and go over the field occasionally with a hoe and cut out any weeds or bunches of grass that may have been missed while cultivating. 


\section{TOPPING.}

When about half of the plants have begun to develop seed heads, or bloom out, the field is ready to be gone over and topped. This process consists simply in breaking the tops out so that the leaves will become larger and more fully developed. The number of leaves to be left on the plant is to be determined by the man doing the topping. He must be able to judge each and every plant and he should top the plants so as to make them, as nearly as possible, mature at the same time. Topping is a very important part of tobacco culture, because topping too low will cause the leaves to be coarse and thick, and topping too high will cause them to fall short of their growth. Uneven topping will cause uneven ripening in the field, thus making harvesting tedious and giving trouble all the way through.

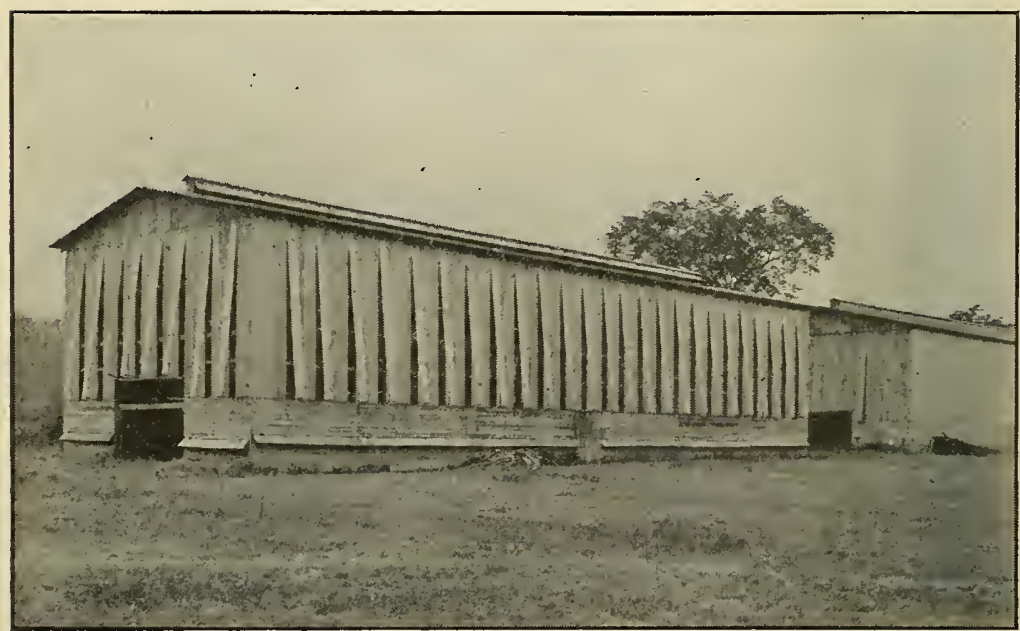

An Ideal Type of Barn for Air Curing, with Ventilators Along the Peak of the Roof, Adapted to the Use of Heat in Curing.

\section{SELECTION OF SEED PLANTS.}

In selecting seed plants, close attention should be given to all the points that go to make up the ideal plant, according to the standard which the grower should have clearly in mind. The largest plants in the richest part of the field are 
not necessarily best for seed purposes. In order to have pure strains of seed. it is necessary to cover the seed head during the blossoming period so as to prevent mixing or crossing with inferior plants or suckers due to the passing of insects from flower to flower on different plants. For this purpose an ordinary light weight but strong paper bag of about the 12 pound size is satisfactory. The bag should have small perforations made so as to give the seed head air. These perforations can be easily made with a sewing machine, the thread having first been removed from the needle. The seed head should be bagged a day or two before the first flowers have opened. The bag should be left on about three weeks and may then be removed so as to allow the seed to mature in the sun. Care should be taken to keep all blooms plucked out after the bags have been removed. A record of each seed planit and of each seed head should be kept, because after tobacco has been cured it may be that some plants will have more desirable features than others.

After the seed has become thoroughly dry, it should be shelled out, cleaned, and graded in a tobacco seed grader. The grader is a very simple device consisting of a long glass tube, connected to a foot bellows by means of a small rubber hose. In the bottom of the glass, is fixed a wire gauze to keep the seed from run ing through. The grad-

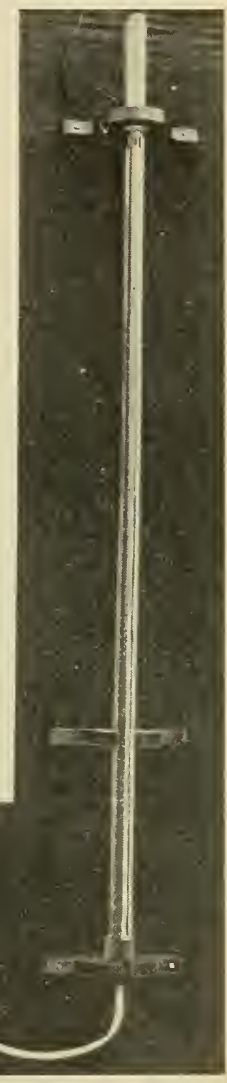

Device for Cleaning Tobacco Seed. ing is done by putting the seed into the glass tube and by air pressure, blowing the light and immature seed over the top of the glass, leaving only the strong heavy seed in the tube. This machine will clean about one ounce of seed at a time, and it will take about five minutes to clean each ounce. There is no danger of mixing seed as only a smooth glass tube contains the seed, and after cleaning one lot, the seeds are all poured out and the tube well cleaned before putting in any more. 


\section{HARVESTING.}

Only two methods of harvesting tobacco are employed in this state. In one method the plant is split to within about six inches of the ground and is then cut and placed astride a stick and left in the field until wilted. In some cases, the stick is stuck into the ground, while in others it is left flat on the ground, but in either case the tobacco is allowed to wilt before being hauled to the barn. In the second method the

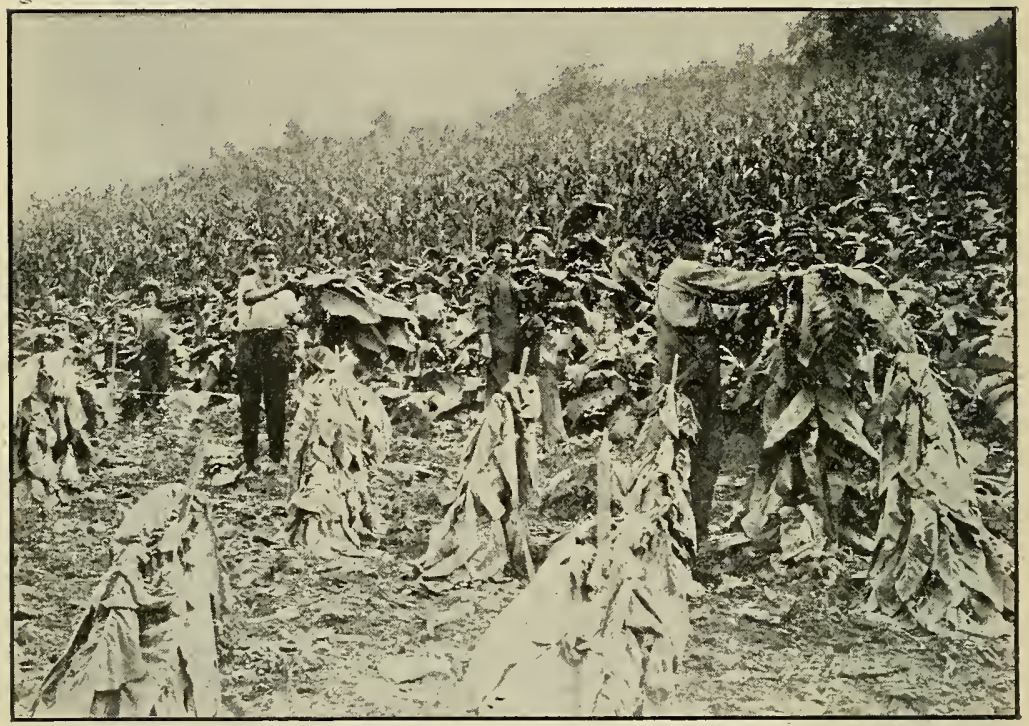

Showing Method of Spudding Tobacco.

tobacco is handled in much the same way except instead of splitting the stalk, it is first cut and then forced on the stick by the use of a sharp spear called a "spud." The "spud" is about eight inches long and is made to slip down over the end of the stick, the latter, of course, first being sharpened. This method is spoken of as "spudding." It is difficult to say just which method is the better, though it is an evident fact that a plant that has been split will cure more quickly than one that has been spudded, and will no doubt give better results for late cutting. One method is about as rapid as the other.

The sticks upon which the tobacco is placed are usually four or four and one-half feet long, and will hold from five to 
eight plants of tobacco, the number being determined by the size of the plants. After the tobacco has wilted enough so that it can be handled without breaking, it is hauled to the barn and hung on the tier poles, the sticks being placed about 12 inches apart. Care should be taken in hanging the tobacco in the barn. The plants should be well spaced on the sticks, and the leaves all left to hang as free as possible. It is a good idea to shake the stalks well. This shaking will separate any leaves that may be stuck together, thus preventing them from probable house-burning.

\section{CURING.}

There are too many changes that take place in curing tobacco to try to describe the process in full detail, but the subject is so important that it should be given some consideration. The prime requisite for curing tobacco properly is to have a good barn and to have it well ventilated. Have the doors and windows closed at night and on foggy days. During rainy weather when the air in the barn becomes saturated with moisture it may be necessary to build fires under the tobacco in order to prevent damage by house-burn. The common open curing shed as used in this state should be displaced by good closed barns with windows and ventilators in them. With poorly constructed curing sheds a grower has no control over unfavorable weather conditions and the tobacco may be considerably damaged in the process of curing, thus reducing its value greatly. When weather conditions are favorable, tobacco can be cured very well in open sheds, but stich conditions cannot be depended upon. Tobacco in an open shed will damage after having been cured. A well ventilated barn could be built for an amount of money equal to that lost by the open curing shed in two or three crops. Such a barn need not be expensive, as has been shown by some good growers.

\section{STRIPPING AND GRADING.}

When tobacco is thoroughly cured it is ready for stripping but it is better, before stripping, to allow it to go through one or two freezes. This, however, may prevent early stripping which in some cases may be necessary. Consequently, it cannot always be allowed to freeze before stripping.

Stripping and grading tobacco is a very particular part of tobacco production and should be given the closest possible attention. Tobacco is graded into the following 
grades: "Flyings," "Trash," "Lugs," "Bright Leaf," "Red Leaf," "Tips," and "Green" or "Damaged."

The grades should be erenly classed while tying; all Iong leaves should be tied separately from the short ones. This will make, from each grade, two or three sub-grades. It is only necessary, howerer, to keep the grades separate. Farmers often do not understand why their tobacco does not bring the same price as their neighbors' when their tobacco is of equal quality, but this state of affairs is easily answered after examining the tobacco of the different growers as placed on the market. It may be seen that one grower has graded and classed his tobacco more carefully, making his better grades show off to better advantage and thus obtaining a higher price for them.

\section{SUMMARY.}

1. The value of the tobacco sold in this state amounts to more than a half million dollars.

2. Tobacco growers should follow a definite rotation in which a winter corer crop and a legume are provided.

3. Introduced rarieties of Thite Burley grown from selected seed give promise of proving superior to the standard variety that is grown in all the tobacco districts of the state.

4. Nitrogen influences the yields of tobacco on the soils of this state more than does either potash or phosphoric acid.

5. A combination of all three plant food constituents produced the highest average yield of tobacco and an application of about 700 pounds of a high grade fertilizer containing not less than $4 \%$ of nitrogen was profitable.

6. To secure good seed, the blooms should be grown under paper bags on carefully selected plants and when harvested the seed should be graded with a tobacco seed grader.

7. The common open tobacco curing sheds used in this state are a cause of poorly cured tobacco. They should be replaced by closed, well ventilated tobacco barns which need not be expensive.

8. Stripping and grading tobacco require very careful attention, and well graded tobacco will command much higher prices than the same tobacco poorly graded. 

